\title{
EFFECTS OF PLANT-DERIVED IMMUNOMODULATORS AND LIZAK PREPARATION IN VITRO TAKEN SEPARATELY OR IN COMBINATION ON THE IMMUNE FACTORS OF PALATINE TONSILS OF CHILDREN WITH CHRONIC TONSILLITIS
}

\author{
${ }^{I}$ National medical academy of post-graduate education \\ named after P.L. Shupik, Kyiv, Ukraine; \\ ${ }^{2}$ State Institution «O.S. Kolomiychenko Institute of Otolaryngology \\ of National Academy of Medical Sciences of Ukraine», Kyiv, Ukraine
}

\section{Introduction}

In most cases, chronic inflammatory diseases of the upper respiratory tract of both microbial and viral origin occur due to the immune deficiency of systemic and local nature $[2,12,14,15]$. Among a large number of immunomodulation agents, a special role belongs to plant preparations, which are characterized by relative harmlessness and high efficiency, both in case of systemic and local use [9, 12]. The clinical and immunological efficacy of Esberitox plant preparation (Schaper \& Brummer, Germany) in a number of diseases of viral and microbial origin has been shown $[4,5]$. The composition of the preparation contains extracts of Baptisia root, Echinacea purpurea and Echinacea pallida roots, Thuja young shoots and leaves. Sinupret and Imupret obtained by phytoneering method (Bionorica AG) and having sufficient substantiation of its use in otolaryngological clinic are of great significance in immunocorrection $[10,11]$.

In a series of clinical and immunological studies in children with acute respiratory viral infections and chronic tonsillitis, as well as in vitro experiments with tonsil cells, it was shown that the antiseptic preparation Lizak containing muramidase has a pronounced dosedependent effect on the cellular and humoral local immunity factors $[10,13]$. Particular attention was paid to the formation of interferons by tonsil cells, which was intensified in the presence of the preparation, as well as to the discovery of regenerative properties of Lizak preparation in relation to tissues of various histogenesis. It seemed advisable to study the possibility of using plant-derived immunomodulators together with an antiseptic preparation to identify their synergistic effect, which may contribute to a more effective treatment of infectious and inflammatory diseases of the upper respiratory tract. Background research was carried out in vitro on tonsil cells of children with chronic tonsillitis who underwent tonsillectomy as medically indicated.

\section{Materials and methods}

The study was performed on cell suspensions obtained from palatine tonsils of children after tonsillectomy. Cell suspensions were prepared according to the recommendations of O.F. Melnikov [8] and adjusted to a concentration of 2 million/ml in medium 199 (Pan Eco, $\mathrm{RF}$ ) with $40 \mathrm{mg} / \mathrm{ml}$ gentamicin (Borshchahivskyi CPP, Ukraine), 5\% fetal bovine serum, $290 \mathrm{mg} / \mathrm{ml}$ glutamine, vitamin concentrate (Serva, Germany).Then, $0.1 \mathrm{ml}$ sterile filtrate from Lizak preparation, which was prepared from a tablet, pulverized in $10 \mathrm{ml}$ Hanks' sterile solution and filtered through the Millipore filter (Czech Republic), was added to the cells. It was cultivated in EC $160 \mathrm{CO}_{2}$ incubator (Turkey) for 24 hours. In the control, a sterile starch filtrate was added instead of the filtrate from the preparation. Separately, the solutions 
of Imupret and Esberitox preparations were prepared, which were added to the culture with or without Lizak at a dose of $10 \mathrm{mg}$ of solid matter per sample. After cultivation, the levels of proinflammatory cytokine-interleukin- $1 \beta$, pro-allergic factor-interleukin-4, Th-1 - derivative of cytokine - interferon- $\gamma$ were studied in the supernatant using the «Tsitokin LLC» reagent kits (RF), as well as tissue regeneration factor - transforming growth factor $-\mathrm{TGF}-1 \beta$ (Lab Line (Austria)). The preparation was prepared from the cell pellet (drop method, E.A. Kost, 1968), in which the relative nonviable cell count was determined in a sample with trypan blue using a light microscope (Olympus CX21FS1).

The statistical analysis was performed using Student's t-distribution [1].

\section{Results}

The data on the effects of preparations on cell viability are presented in Figure 1, which shows that plant-derived immunomodulators, in contrast to Lizak preparation, did not significantly increase the survival percentage of lymphoid cells of the palatine tonsils during twenty-four hours when cultivated in vitro. Cocultivation with Lizak preparation increased the percentage of viable cells, especially cocultivation with Esberitox and Lizak preparations $(\mathrm{P}=0.05)$.

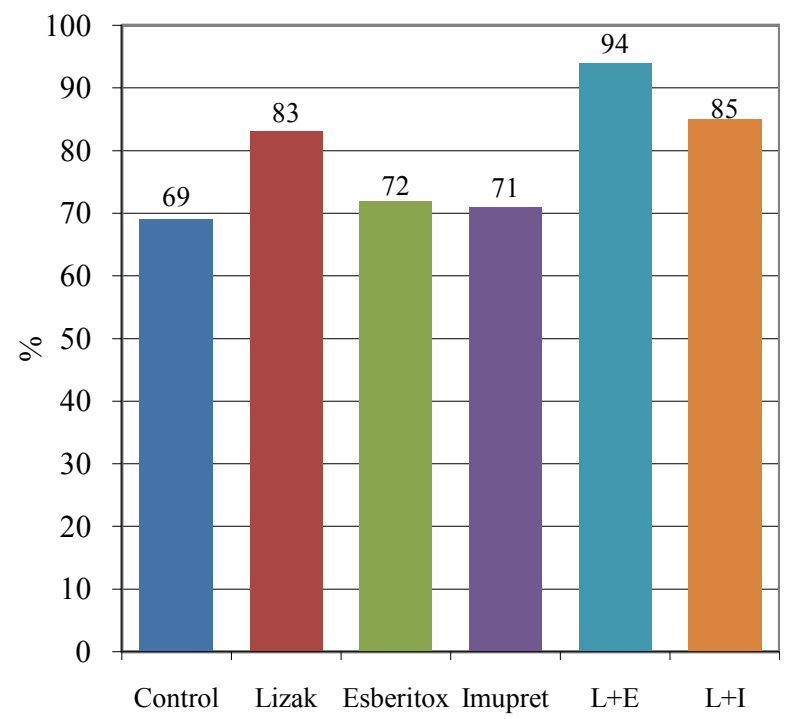

Figure 1. Relative content of viable cells in the tissue culture of tonsils in cultivation with different preparations.
Subsequently, the level of IL-4, which is one of the major factors in the activation and excitation of B-lymphocyte proliferation, produced mainly by Th- 2 cells and IFN- $\gamma$ - the socalled immune interferon, produced by Th-1 cells, activated agents, cytokines or mitogens, and NK cells, in the culture fluid of tonsil cells, indicating the activation of different parts of the immune system, under the influence of immunocorrectors in vitro was investigated.

The study of the effect of immunomodulatory preparations on the production of IL-4 and IFN- $\gamma$ in the tonsil cells in vitro showed that the level of IL-4 in children with chronic tonsillitis did not significantly change from baseline (without preparations). These data are presented in Table.

The level of IFN- $\gamma$ varied mainly under the action of immunomodulators (both Esberitox and Imupret). Lizak used in combination with immunomodulators (especially with Esberitox) showed a significant increase in interferon- $\gamma$ production $(\mathrm{P}<0.05)$.

Determination of the pro-inflammatory cytokine IL-1 $\beta$ in the same culture fluid showed that its level in the presence of Lizak was lower than that of immunomodulators separately or in combination with Lizak preparation, i.e. Lizak actively inhibited interleukin-1 $\beta$ synthesis by cells (Figure 2).

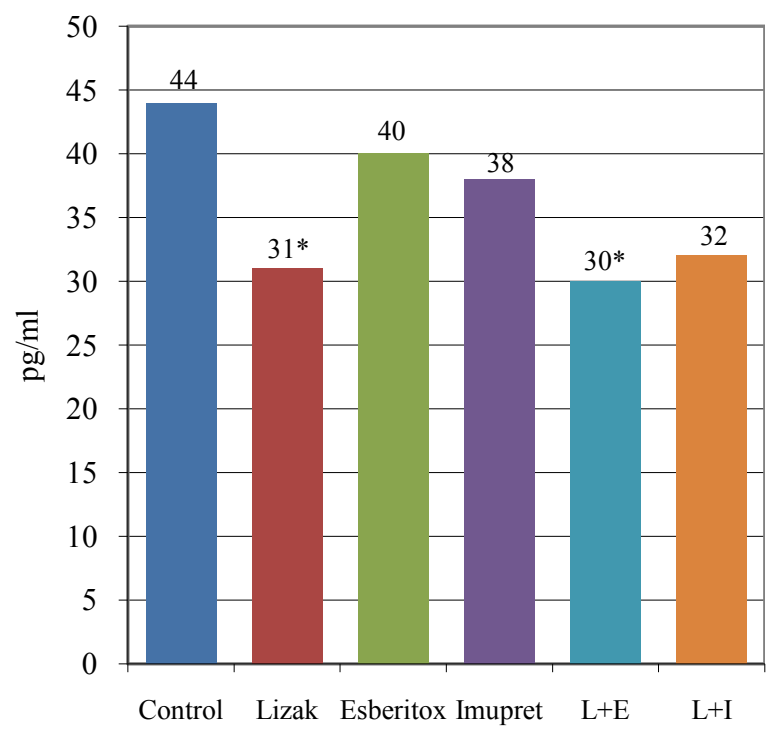

Figure 2. The content of interleukin-1 $\beta$ in the culture fluid after the action of different preparations on the cells of tonsils. ${ }^{*} \mathrm{P}=0.05$ in relation to $« \mathrm{Con}-$ trol». 
Changes in the production of IL-4 and INF- $\gamma$ by lymphocytes of tonsils of children with chronic tonsillitis in vitro under the action of immunomodulators

\begin{tabular}{|l|c|c|c|}
\hline \multicolumn{1}{|c|}{ Preparations } & Interferon-gamma, $\mathrm{pg} / \mathrm{ml}$ & Interleukin-4, $\mathrm{pg} / \mathrm{ml}$ & Number of specimens \\
\hline Without preparation & $19.0(8-29)$ & $6.5(4-11)$ & 10 \\
\hline Lizak & $29.5(20-33)$ & $6.0(3-12)$ & 10 \\
\hline Esberitox & $37.5(25-45)^{*}$ & $7.5(5-11)$ & 9 \\
\hline Imupret & $38.5(22-50)^{*}$ & $9.5(4-14)$ & 10 \\
\hline Lizak+ Esberitox & $65.5(40-78)^{* *}$ & $10.2(5-15)$ & 10 \\
\hline Lizak+ Imupret & $45.0(31-60)^{*}$ & $11.5(5-16)$ & \\
\hline
\end{tabular}

$* \mathrm{P}=0.05 ; * * \mathrm{P}<0.05$

Considering the fact that Lizak preparation has not only antibacterial $[6,11]$, but also regenerative properties [13], and activates the production of the transforming growth factor TGF-1 $\beta$, which is a marker of tissue regeneration [3], it seemed appropriate to determine the presence of this factor in supernatant after culturing of tonsil cells of children with chronic tonsillitis with plant-derived immunomodulators separately and in combination with Lizak preparation. It was found that both plantderived immunomodulators had a stimulating effect to a greater extent with Lizak preparation used separately (Figure 3). Since plant-derived immunomodulators did not change the initial level of TGF-1 $\beta$ in tonsil cell culture, it can be assumed that they have an enhancing effect on the mechanisms of formation of this cytokine under the action of Lizak preparation. At the same time, the effect of Lizak and Imupret was of a tendency nature, and in combination of Lizak with Esberitox, it was significant $(\mathrm{P}<0.02)$

When analyzing the obtained data, the extensive effect of Lizak preparation in many functional manifestations was different from the action of plant-derived preparations, namely: plant-derived preparations did not have any effect on cell viability in culture, did not reduce the level of the pro-inflammatory cytokine interleukin-1 $\beta$ and did not stimulate the production of the regeneration factor TGF-1 $\beta$. At the same time, the combined use of plantderived preparations and the antibacterial preparation Lizakin cell culture of tonsils was accompanied by an increase in cell viability compared to the use of Lizak preparation sepa- rately, the stimulation of the regulatory antiviral factor interferon- $\gamma$ and an increase in the production of tissue regeneration factor. Plantderived immunomodulator Esberitox was more effective when combined with Lizak preparation than Imupret. The obtained results experimentally substantiate the possibility of using Lizak preparation in combination with plantderived immunomodulators to increase the effectiveness of treatment of infectious and inflammatory diseases of the upper respiratory tract.

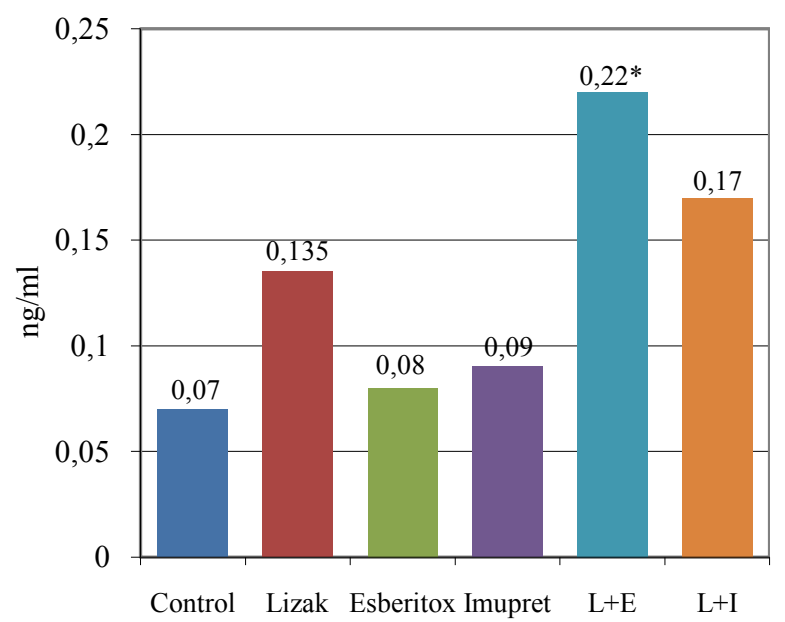

Figure 3. The effect of preparations on the production of transforming growth factor TGF-1 $\beta$ by cells of the palatine tonsils of children with chronic tonsillitis in vitro.

\section{Conclusions}

1. Esberitox and Imupret significantly $(\mathrm{P}=0.05)$ increased the production of $\gamma$-IFN by the cells of the palatine tonsils with a separate application 2 times with respect to the control group, and in the presence of the drug Lizak 
3.4 times with respect to the control group and 1.7 times for groups with separate use of Imupret and Esberitox.

2. Stimulation of transforming growth factor TGF-1 $\beta$ and cell viability of the tonsils did not change significantly under the separate influence of the drugs and was significantly $(\mathrm{P}<0.05)$ 2-3 times higher when combined use of the drugs Lizak and Esberitox relative to all compared groups and to control group.

\section{References}

1. Gubler EV. [Mathematical methods of the analysis and recognition of pathological processes]. Moscow: Medicine; 1978. 294 p. [In Russian].

2. Bredun O, Melnykov O. Immunological aspects in tht selection of tonsils pathology treatment methods. The $8^{\text {th }}$ International Symposium of Tonsils. Zurich; 2013. Abstr. 02.

3. Drannik G. [Clinical immunology and allergology]. Kyiv: Poligrafplius; 2010. 552 p. [In Russian].

4. Ershov FI, Norovlianskii AN, Mezentseva MV. [Early cytokine reactions in viral infections]. Cytokines and inflammation. 2004;3(1):3. [In Russian].

5. Kurchenko IF, Svidro SV, Savchenko VS. [The effect of Esberitox in vitro on mononuclears of peripheral blood of patients with herpes virus infection]. Immunology and allergology: Science and practice. 2016;1-4:19. [In Ukrainian].

6. Marushko Yu, Melnikov O, Movchan O, Lysovets O. Content of antimicrobial peptides in oropharyngeal secretions of children suffering from acute respiratory diseases. X Anniversary UkrainianPolish-Belorussian Conference "Physiology and Pathology of Respiration: Advances in basic research and clinical applications" (Kyiv). Physiological journal. 2013;59(4):22.

7. Melnykov O, Zabolotny D. The concept of diagnosing secondary immunodeficiency states based on determination of 16 immunoglobulins in the secretions. International Journal on Immunorehabilitation. 2004;6(2):235.

8. Melnykov OF. [Immunological aspects of the genesis of chronic tonsillitis and regulation of

functional activity of palatine tonsils]. [Dissertation]. Kyiv: Institute of Physiology of the Academy of Sciences of USSR; 1981. 294 s. [In Russian].

9. Melnykov OF, Peleshenko NA, Zabolotnaiia DD, Rylskaia OG. [Immunomodulation by plantderived preparations in the therapy of inflammatory diseases of the upper respiratory tract]. Medical Nature. 2013:Sect. A: 108. [In Russian].

10. Melnykov OF, Rylskaia OG, Tsymar AV, Peleshenko NA. [Imupret as plant-derived immunomodulator or and adaptogen]. Medical Nature. 2013: Sect. B; 2(14):70. [In Russian].

11. Melnykov OF, Zaiats TA, Tymchenko MD, Byl' BN, Zemliak TB. [Study of the effect of Lizak preparation on cellular and humoral immune factors in vitro. Health of Ukraine. 2014;4:11. [In Russian].

12. Melnykov OF, Zabolotnyi DI, Kishchuk VV, Bredun AYu, Rylskaia OG. [Immunology of chronic tonsillitis]. Kyiv: Logos; 2017. 192 p. [In Russian].

13. Melnykov OF, Kryvokhatskaia LD, Levandovskaia VI, Faraon IV, Tsymar AV. [Nonantibacterial effects in the mechanisms of action of local antiseptics]. Otolaryngology. 2019;1-s:72. [In Russian].

14. Yamanaka N. Moving towards a new era in the research of tonsils and mucosal barriers. Adv Otorhinolaryngol. 2011;72:6-19. doi: 10.1159/ 000324586.

15. Tjabringa GS, Vos JB, Olthuis D, Ninaber DK, Rabe KF. FEMS Immunol Med Microbiol. 2005 Aug 1;45(2):151-8. doi: 10.1016/j.femsim.2005.03.004. 


\title{
EFFECTS OF PLANT-DERIVED IMMUNOMODULATORS AND LIZAK PREPARATION IN VITRO TAKEN SEPARATELY OR IN COMBINATION ON THE IMMUNE FACTORS OF PALATINE TONSILS OF CHILDREN WITH CHRONIC TONSILLITIS
}

\author{
Bredun $O^{1}$, Melnikov $O^{2}$, Tymchenko $M^{2}$ \\ ${ }^{I}$ National medical academy of post-graduate education named after P.L. Shupik, Kyiv, Ukraine; \\ e-mail:abredun@ukr.net \\ ${ }^{2}$ State Institution «O.S. Kolomiychenko Institute of Otolaryngology of National Academy of Medical Sciences \\ of Ukraine», Kyiv, Ukraine; e-mail: amtc@kndio.kiev.ua
}

Abstract

Introduction: Chronic inflammatory diseases of the upper respiratory tract of both microbial and viral origin occur due to the immune deficiency of systemic and local nature. Among a large number of immunomodulation agents, a special role belongs to plant preparations, which are characterized by relative harmlessness and high efficiency, both in case of systemic and local use and they are often combined with antimicrobial agents, therefore the aim of the study was to investigate their effect on the reactions and condition of lymphoid cells of tonsilswith separate and combined use in vitro.

Methods: Cell suspensions were prepared mechanically and adjusted to a concentration of $2 \mathrm{million} / \mathrm{ml}$ in medium 199 with additives. Then, Lizak preparation was added to the cells and starch solution was used in control. Imupret and Esberitox preparations were added to the culture with or without Lizak preparation. After cultivation, the levels of proinflammatory cytokine - Interleukin-1 $\beta$, pro-allergic factor - Interleukin- 4 , Th-1 - derivative of cytokine - interferon- $\gamma$ were studied in the supernatant using the «Tsitokin LLC» reagent kits (RF), as well as tissue regeneration factor - transforming growth factor -TGF-1 $\beta$ (Austria). The preparation was prepared from the cell pellet, in which the relative nonviable cell count was determined in a sample with trypan blue using a light microscope (Olympus CX21FS1).The statistical analysis was performed using Student's t-distribution.

Results: Plant-derived preparations did not have any effect on cell viability in culture, did not reduce the level of the pro-inflammatory cytokine interleukin- $1 \beta$ and did not stimulate the production of the regeneration factor TGF-1 $\beta$. At the same time, the combined use of plant-derived preparations and the antibacterial preparation Lizak in cell culture of tonsils was accompanied by an increase in cell viability compared to the use of Lizak preparation separately, the stimulation of the regulatory antiviral factor interferon- $\gamma$ and an increase in the production of tissue regeneration factor.

Conclusion: The immunomodulating properties of the antibacterial preparation Lizak and plant-derived immunomodulator Esberitox significantly differ in the points of application.

Both plant-derived preparations stimulated the production of $\gamma$-interferon by tonsil cells in the presence of Lizak preparation, the transforming growth factor TGF-1 $\beta$, the viability of tonsil cells was the highest with the combination of Lizak and Esberitox.

Key words: plant-derived preparations, antibacterial agents, tonsil cell cultures, cytokines.

\section{ВПЛИВ ІМУНОМОДУЛЮЮЧИХ ПРЕПАРАТІВ РОСЛИННОГО ПОХОДЖЕННЯ, ОКРЕМО АБО В КОМБІНАЦІЇ З ПРЕПАРАТОМ «ЛІЗАК» IN VITRО, НА РЕАКЦІЇ ТА СТАН ЛІМФОЇДНИХ КЛІТИН МИГДАЛИКІВ ДІТЕЙ 3 ХРОНІЧНИМ ТОНЗИЛІТОМ}

\author{
Бредун ОЮ ${ }^{1}$, Мельников ОФ ${ }^{2}$, Тимченко МД \\ ${ }^{1}$ Національна медична академія післядипломної освіти ім. П.Л. Шупика, Київ, Украӥна, \\ e-mail:abredun@ukr.net;

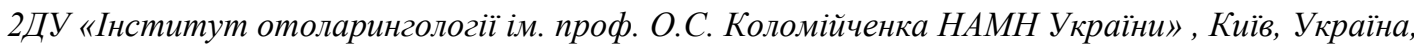 \\ e-mail:amtc@kndio.kiev.ua
}

Анотація

Bcmyn: Хронічні запальні захворювання верхніх дихальних шляхів як бактеріального, так і вірусного походження виникають через імунну недостатність системного та місцевого характеру. Серед великої кількості імуномодулюючих засобів особлива роль належить препаратам рослинного походження, які мають високу ефективність та безпечність як при системному, так і при локальному застосуванні, i ïх часто поєднують з антимікробними засобами.

Метою дослідження було дослідити вплив імуномодулюючих препаратів рослинного походження на реакції та стан лімфоїдних клітин мигдаликів при роздільному та комбінованому застосуванні in vitro. 
Матеріали та методи: Клітинні суспензії готувались механічним способом і доводились до концентрації 2 млн/мл у середовищі 199 з добавками. Потім до клітин додавався препарат «Лізак» і для контролю використовувався розчин крохмалю. Препарати «Імупрет» та «Есберітокс» додавались до культури 3 препаратом «Лізак» або без нього. Після культивування у супернатанті визначались рівні прозапальних цитокінів - інтерлейкіну-1 $\beta$, проалергічного фактору - інтерлейкіну-4, Th-1 - похідного цитокіну - інтерферону- $\gamma$. Використовувались набори реагентів ТОВ «Цитокін» (РФ), а також фактор регенерації тканин TGF-1 $\beta$ (Австрія). Препарат готувались 3 клітинних гранул, в яких відносна кількість життєздатних клітин визначалась у зразку з трипановим синім за допомогою світлового мікроскопа Olympus CX21FS1. Cтатистичний аналіз проводився за допомогою t-тесту Стьюдента.

Результати: Препарати рослинного походження не мали жодного впливу на життєздатність клітин у культурі, не знижували рівень прозапального цитокіну - інтерлейкіну- $1 \beta$ і не стимулювали продукцію фактору регенерації TGF-1 $\beta$. У той же час комбіноване використання препаратів рослинного походження та протимікробного препарату «Лізак» у культурі клітин мигдаликів супроводжувалось підвищенням життєздатності клітин порівняно із застосуванням препарату «Лізак» окремо, стимуляцією регуляторного антивірусного фактору інтерферону- $\gamma$ та збільшенням продукції фактору регенерації тканин.

Висновки: Імуномодулюючі властивості протимікробного препарату «Лізак» та імуномодулятору «Есберітокс» рослинного походження значно відрізняються за векторами застосування.

Обидва рослинні препарати стимулювали продукцію $\gamma$-інтерферону і трансформуючого фактору росту TGF-1 $\beta$ клітинами мигдаликів у присутності препарату «Лізак», життєздатність клітин мигдаликів була найвищою при комбінованому застосуванні препаратів «Есберітокс» та «Лізак».

Ключові слова: рослинні препарати, протимікробні засоби, клітини мигдаликів, цитокіни. 